\title{
STRATEGI PEMBERDAYAAN ANAK MELALUI WADAH PARTISIPASI ANAK SEBAGAI UPAYA PEMAJUAN HAK ASASI MANUSIA
}

\author{
1Irma Sahvitri Lawado dan ${ }^{2} \mathrm{Na}$ 'imah \\ 1,2 Fakultas Hukum - Universitas Lumajang \\ ${ }^{1}$ savitri_rabbani@yahoo.co.id
}

\begin{abstract}
Human rights are both goals and means of development. The right to life, security, freedom of expression and freedom from all forms of oppression shall be respected by anyone. The social and criminal cases are as a negative effects of development in the era of globalization that befell children is one of the disturbances in the process of growing children who need attention in the form of prevention and mitigation in order to prepare the situation and conditions and a conducive environment, for the efforts of growth and development of children optimally because he is a citizen who has the same position and opportunity to the process development, and the outcome of development. It is necessary to attempt to internalize human rights as a form of partial action on the rights of children through the empowerment of children in child participation venues, which is expected to be a solution that bridges more effective communication with all related lines, so that the promotion of children's rights as protection of children's rights can materialized. Because by empowering children it will give meaning that children participate in development.
\end{abstract}

Keywords: The protection of children right, children empowerment, institutions of child participation

\section{Abstrak}

Hak asasi manusia adalah tujuan dan sarana pembangunan. Hak untuk hidup, keamanan, kebebasan berekspresi dan kebebasan dari segala bentuk penindasan harus dihormati oleh siapa pun. Kasus-kasus sosial dan kriminal adalah sebagai dampak negatif dari perkembangan di era globalisasi yang menimpa anak-anak adalah salah satu gangguan dalam proses tumbuh kembang anak yang membutuhkan perhatian dalam bentuk pencegahan dan mitigasi untuk menyiapkan situasi dan kondisi dan lingkungan yang kondusif, untuk upaya pertumbuhan dan perkembangan anak secara optimal karena ia adalah warga negara yang memiliki kedudukan dan peluang yang sama untuk proses pengembangan, dan hasil perkembangan. Diperlukan upaya untuk menginternalisasi hak asasi manusia sebagai bentuk tindakan parsial atas hak-hak anak melalui pemberdayaan anak-anak di tempat-tempat partisipasi anak, yang diharapkan menjadi solusi yang menjembatani komunikasi yang lebih efektif dengan semua jalur terkait, sehingga promosi hak-hak anak sebagai perlindungan hak anak dapat terwujud. Karena dengan memberdayakan anak-anak itu akan memberi makna bahwa anak berpartisipasi dalam perkembangan.

Kata kunci: Perlindungan hak anak, pemberdayaan anak, lembaga partisipasi anak 


\section{PENDAHULUAN}

Anak merupakan bagian dari generasi muda sebagai salah satu sumberdaya manusia yang merupakan potensi serta penerus cita-cita perjuangan bangsa yang memiliki peranan strategis serta mempunyai ciri dan sifat khusus serta memerlukan pembinaan dan perlindungan dalam rangka menjamin pertumbuhan dan perkembangan fisik, mental dan social secara utuh, serasi, selaras dan seimbang (Indonesia, 1967). Cita-cita kemerdekaan Indonesia adalah mewujudkan bangsa Indonesia yang adil dan makmur. Salah satu syarat untuk mencapai harapan ini adalah pemberdayaan perempuan serta perlindungan terhadap perempuan dan anak. Negara baru akan terbebas dari kemiskinan yaitu hanya apabila perempuan dan anak Indonesia berada dalam garis aman (Indonesia.

Kementerian Pemberdayaan Perempuan dan Perlindungan Anak, n.d.). Maraknya fenomena sosial sebagai dampak dari globalisasi ekonomi, kemajuan teknologi informasi dan perdagangan bebas ternyata tidak menguntungkan dalam perspektif tumbuh kembang dan perlindungan anak. Kegiatan pembangunan yang bersifat multidimensional yang mengakibatkan adanya interdependensi antar aktor kunci menuntut adanya kemitraan yang kuat yang harus didasari rasa saling percaya dan saling menguatkan (Sumaryo Gs. \& Rangga, 2015, pp. 27-28). Meski hasil positif yang didapatkan dari pembangunan nasional telah banyak dirasakan oleh masyarakat, terutama dibidang pendidikan dimana data Komisi Perlindungan Anak Indonesia (KPAI) mencatat terdapat 83,83 persen anak yang berusia 5 - 17 tahun masih berstatus sekolah pada tahun 2014, namun demikian masih tetap ditemukan angka putus sekolah pada jenjang pendidikan sekolah dasar sebesar 1,41 persen, pada jenjang pendidikan SMP mencapai 2, 24 persen, serta pada jenjang seklah menengah mencapai angka 1,74 persen. Dari anak pada usia 7 hingga 17 tahun yang putus sekolah tersebut disebabkan karena ketidakadaan biaya sekolah sebesar 39, 48 persen, karena anak bekerja sebesa 9, 77 persen dan kendala karena sekolah jauh sebesar 3, 92 persen, 4,86 persen karena menikah atau mengurus rumah tangga serta karena alasan lain. Bahkan angka perkawinan dini yang terjadi pada usia anak juga masih sangat tinggi mencapai 34,5 persen sehingga sangat memprihatinkan karena maraknya perkawinan dini tersebut berpotensi terhadap meningkatnya angka kematian ibu dan bayi di Indonesia karena faktor ketidaksiapan organ reproduksi anak perempuan maupun potensi kerugian hak perempuan lainnya maupun anak dari hasil perkawinan tersebut karena perkawinannya tidak dilakukan pencatatan (Setyawan, 2014).

Kasus sosial lain yang marak terjadi serta menimpa anak seperti kekerasan terhadap anak baik dari segi fisik, psikis, seksual baik dilingkungan rumah maupun sekolah dan eksploitasi ekonomi dengan menjadikan anak sebagai pengemis dan pengamen, putus sekolah, dan lain-lain termasuk diantaranya jika anak terpaksa berkontak dengan sistem pengadilan pidana karena disangka, didakwa atau dinyatakan terbukti bersalah melanggar hokum; menjadi 
korban akibat perbuatan pelanggaran hukum yang dilakukan oleh oranglain maupun anak yang melihat, mendengar merasakan atau mengetahui suatu peristiwa pelanggaran hukum (Setyawan, 2014), sehingga potensi pelanggaran terhadap hak anak dikhawatirkan akan bisa terus terjadi sehingga menjadi kwajiban bersama seluruh elemen warganegara untuk bisa mencegah dan menanggulangi potensi masalah terhadap anak- anak tersebut dalam rangka untuk mempersiapkan situasi dan kondisi serta lingkungan yang kondusif bagi upaya pertumbuhan dan perkembangan anak secara optimal. Salah satu penyebab mengapa semua itu terjadi adalah karena orang dewasa tidak mempunyai keinginan yang kuat untuk mendengarkan suara anak, anak tidak diberikan ruang, kesempatan dan waktu untuk turut berpartisipasi dalam menentukan hal-hal yang menyangkut dirinya. Banyak orang dewasa beranggapan bahwa segala sesuatu yang cocok bagi orang dewasa maka akan cocok pula bagi anak-anak namun faktanya anak-anak mempunyai dunia sendiri yang tidak mudah dimenngerti oleh orang dewasa (Indonesia. Kementerian Pemberdayaan Perempuan dan Perlindungan Anak, 2011b). Dalam kajian psikologi anak bukan manusia dewasa yang terjelma dalam bentuk mini akan tetapi ia adalah otonom yang sedang berproses untuk menemukan jati dirinya. Tugas orang dewasa adalah membantu anak dalam tumbuh kembangnya serta senantiasa memberikan pencerahan dan bukan membekuk, menjajah, menindas dan mengalahkannya sehingga anak harus melakukan seperti apa yang dikehendaki orang dewasa. Bahkan dikatakan oleh Peter Newel tentang perlindungan anak bahwa beberapa alasan subyektif dari sisi keberadaan anak sehingga ia membutuhkan perlindungan adalah Bahwa biaya pemulihan atau recovery akibat kegagalan dalam memberikan perlindungan sangat tinggi jika dibandingkan dengan biaya yang dikeluarkan jika anak dengan memperoleh perlindungan:

a. Anak-anakakan sangat berpengaruh baik langsung dan berjangka panjang atas perbuatan (action) ataupun tidak adanya/dilakukannya perbuatan (unaction) dari pemerintah maupun kelompok lainnya

b. Anak-anak selalu mengalami pemisahan atau kesenjangan dalam pelayanan publik

c. Anak-anak tidak mempunyai hak suara dan tidak mempunyai lobi untuk mempengaruhi agenda kebjakan pemerintah

d. Anak-anak pada banyak keadaan tidak dapat mengakses perlindungan dan penataan hak-hak anak

e. Anak-anak lebih berisiko dalam eksploitasi dan penyalahgunaan (Rumtianing, 2016, p. 17)

Rasa kasih sayang merupakan merupakan kebutuhan psikis yang paling mendasar dalam hidup dan kehidupan anak karena pada hakikatnya ia tidak dapat melindungi diri sendiri dari berbagai macam tindakan yang menimbulkan kerugian mental, fisik, sosial dalam berbagai kehidupan dan penghidupan sehinga ia harus dibantu oleh oranglain dalam melindungi dirinya 
mengingat situasi dan kondisinya. Anak yang dibesarkan dalam suasana konflik, cenderung mengalami keresahan jiwa yang dapat mendorong anak melakukan tindakan-tindakan negatif yang dikategorikan sebagai kenakalan anak. Kenakalan anak bukan hanya merupakan gangguan terhadap keamanan dan ketertiban masyarakat, tetapi juga mengancam masa depan bangsa dan negara sehingga ia perlu untuk dilindungi dari perbuatan- perbuatan yang merugikan agar anak sebagai penerus bangsa dapat tetap terpelihara demi masa depan bangsa dan negara sehingga dikatakan oleh Arif Gosita, bahwa anak wajib dilindungi agar mereka tidak menjadi korban tindakan dari siapa saja (individu atau kelompok, organisasi swasta maupun pemerintah) baik secara langsung maupun tidak langsung.

Yang dimaksud dengan korban adalah mereka yang menderita kerugian (mental, fisik, sosial) karena tindakan pasif atau tindakan aktif orang lain atau kelompok (swasta atau pemerintah) baik langsung maupun tidak langsung (Gultom, 2008, p. 2).

Kondisi-kondisi yang mengganggu proses tumbuh kembang anak memerlukan adanya tindakan pemihakan (affirmative actions) terhadap anak untuk memenuhi hak-hak anak yang dilakukan secara sadar, terencana, sistematis dan berkelanjutan. karena anak adalah merupakan warganegara yang mempunyai kedudukan dan kesempatan yang sama pula terhadap proses, perkembangan serta hasil dari pembangunan. UUD 1945 menjamin perlakuan khusus tersebut sebagai hak untuk memperoleh manfaat yang sama. Pasal $28 \mathrm{H}$ ayat (2) menyatakan bahwa setiap orang berhak mendapatkan kemudahan dan perlakuan khusus untuk memperoleh kesempatan dan manfaat yang sama guna mencapai persamaan dan keadilan (Indonesia. Kementerian Pemberdayaan Perempuan dan Perlindungan Anak, 2011a). Sebagaimana telah disampaikan melalui materi hukum mengenai hak-hak anak dalam Konvensi Hak-hak Anak kedalam salah satu kelompok hak anak yaitu hak untukberpartisipasi (participation rights) yang meliputi hak anak untuk menyatakan pendapat dalam segala hal yang mempengaruhi anak (the rights of a child to express her/his views in all matters affecting that child) (Wiyono, 2016, p. 35). Upaya menginternalisasikan hak asasi manusia sebagai bentuk tindakan pemihakan terhadap anak melalui pemberdayaan anak dalam wadah partisipasi diharapkan akan menjadi solusi yang menjembatani komunikasi yang lebih efektif sehingga pemajuan hak asasi anak sebagai salah satu upaya perlindungan terhadap anak dapat terwujud.

\section{PEMBAHASAN}




\section{Partisipasi sebagai Hak Asasi (Anak)}

Hak asasi manusia adalah hak yang dimiliki manusia secara kodrati tanpa pengecualian dan keistimewaan bagi golongan, kelompok maupun tingkat sosial manusia tertentu yang meliputi hak atas kehidupan, keamanan, kebebasan berpendapat dan merdeka dari segala bentuk penindasan yang wajib dijunjung tinggi tidak saja oleh setiap individu dari suatu negara yang mengakui keberadaan dan menghargai HAM itu sendiri namun harus pula dijamin oleh negara tanpa ada pengecualiannya. Jaminan yang diberikan oleh negara atas hak-hak tersebut tidak dapat diartikan bahwa hak-hak tersebut lahir setelah negara meratifikasi suatu konvensi internasional tentang HAM atau mengeluarkan peraturan apapun yang menjamin hak asasi warganegaranya namun lebih merupakan tanggungjawab negaradalam menjamin hak-hak yang telah dimiliki oleh setiap warganya secara kodrati dan memperlihatkan penghargaan negara atas hak-haktersebut.

Istilah hak asasi manusia itu sendiri berarti hak tersebut ditemukan dalam hakekat kemanusiaan dan demi kemanusiaan. Anak sebagai salah satu kelompok yang vurnerable dalam masyarakat didalam suatu negara, merupakan kelompok yang juga wajib mendapatkan jaminan atas hak-hak yang dimilkinya secara asasi (Savitri, 2008, p. 3).

Hak asasi manusia merupakan tujuan (end) sekaligus sarana (means) pembangunan. Oleh karena itu HAM ditempatkan sebagai salah satu fokus dari pembangunan. Dari berbagai ragam hak asasi manusia, pada dasarnya pengertian hak adalah sesuatu yang oleh sebab itu seseorang (pemegang) memiliki keabsahan untuk menuntut sesuatu yang dianggap tidak dipenuhi atau diingkari. Penanggungjawab dari perlindungan hak asasi manusia adalah yang pertama yaitu kewajiban pemerintah atau negara hukum untuk mengatur pelaksanaan hak asasi yang berarti pelaksanaan serta pembatasannya demi kepentingan umum, bangsa dan negara; serta kwajiban lain meletakkannya kepada segenap individu warga negara sehingga dapat bersama-sama mempunyai kewenangan dalam upaya perlindungan hak asasi karena didasari oleh beberapa faktor yaitu:

a. Kepentingan HAM tidak hanya menyangkut kepentingan negara semata karena juga menyangkut kepentingan warganegara

b. HAM seutuhnya bersumber pada pertimbangan normative agar manusia diperlakukan sebagaimana martabatnya yang sesungguhnya

c. Operasionalisasi kegiatan HAM menjadi tanggungjawab bersama anatara manusia dalam struktur negara yang saling harus berikteraksi dan harus diwujudkannya (Wiranata, 2009, p. 230)

Sebagaimana telah diatur pula dalam UUD 1945, bahwa dalam rangka menegakkan butir-butir ketentuan hak asasi , diatur pula mengenai hak asasi oranglain serta tanggungjawab negara atas tegaknya hak asasi manusia yaitu bahwa untuk perlindungan, pemajuan, penegakan 
dan pemenuhan hak asasi manusia adalah tanggungjawab negara terutama dalam ini adalah pemerintah (Effendi, 2012, p. 277).

Anak dikelompokkan sebagai kelompok rentan sehingga menuntut pertanggungjawaban orangtua, keluarga, masyarakat, pemerintah dan negara melalui rangkaian kegiatan yang harus dilaksanakan secara berkelanjutan dan terarah demi menjamin pertumbuhan dan perkembangan anak baik fisik, mental, spiritual maupun sosisal, berdasarkan asas nondiskriminasi, kepentingan yang terbaik bagi anak, hak untuk hidup, kelangsungan hidup dan perkembangan serta penghargaan terhadap pendapat anak. Hak asasi anak merupakan bagian dari hak asasi manusia sebagaimana yang termuat dalam Undang-undang Dasar 1945 dan Konvensi Perserikatan Bangsa-bangsa tentang Hak-hak anak sehingga berdasarkan hal tersebut terbukti bahwa pemerintah bersungguh-sungguh menjadi bagian dari masyarakat internasional dalam mengimplementasi dan menginternalisasi hak asasi manusia kedalam penyelenggaraan negara yang dalam kenyataannya juga diiringi oleh peran serta masyarakat secara aktif sebagai wujud dari perilaku yang mendukung sehingga pemaknaan social engineering melalui hukum dapat tercapai (Wiranata, 2009, pp. 239-240).

Sebagai subyek yang memiliki individualitas yang unik dan khas dalam pertumbuhan fisik, perkembangan intelektual, emosioal dan spiritual, anak perlu mendapatkan kesempatan dan keleluasaan untuk mengembangkan segala potensi yang dimilkinya (Djamal, 2016, p. 1). Salah satu hak dalam rangka penyelenggaraan perlindungan hak anak menurut Konvensi Hak Anak adalah hak untuk berpartisipasi yang merupakan hak anak mengenai identitas budaya mendasar bagi anak, masa kanak-kanaknya dan pengembangan keterlibatannya didalam masyarakat luas sehingga dapat memberikan makna bahwa anak ikut menyumbangkan peran dan bukan hanya seorang penerima yang bersikap pasif dalam segala sesuatu yang berkaitan dengan perkembangannya, dimana negara harus menjamin anak-anak untuk mampu mengembangkan pandangannya dalam segala hal yang berpengaruh bagi dirinya sehingga untuk itu ia hrus diberikan kesempatan khusus untuk didengar dalam setiap tata laksana hukum dan administrasi, bebas berekspresi yang mencakup kebebasan untuk mencari, menerima dan memberi segala informasi dan gagasan, berserikat dan menjalin hubungan dengan oranglain serta untuk bergabung dalam atau untuk membentuk himpunan, kecuali jika hal tersebut melanggar hak oranglain, sebagaimana diatur dlam pasal 12, pasal 13 dan pasal 15 Konvensi Hak-hak Anak (Prakoso, 2016, pp. 112-113).

Partisipasi anak adalah keterlibatan anak dalam proses pengambilan keputusan tentang segala sesuatu yang berhubungan dengan dirinya dan dilaksanakan atas kesadaran, pemahaman serta kemauan bersama sehingga anak juga dapat menikmati hasil atau mendapatkan manfaat dari keputusan tersebut karena setiap anak berhak untuk berpartisipasi secara wajar dan berhak menyatakan pendapatnya serta memberikan informasi sesuai dengan 
tingkat kecerdasan dan usianya. Meski secara individu untuk kebutuhan pribadi anak merupakan tanggungjawab dari orangtua namun kebutuhan sosialnya seperti fasilitas kesehatan, pendidikan, rekreasi, perlindungan dari tindakan kekerasan, diskriminasi dan tindakan salah lainnya termasuk pemenuhan hak-hak dasar anak merupakan tanggungjawab dari negara dan masyarakat, sehingga anak-anak perlu mendapat kesempatan seluas-luasnya untuk berpartisipasi dalam pembangunan dan social kemasyarakatan di lingkungannya untuk menjamin agar anak dapat tumbuh berkembang secara optimal baik dari segi fisik, mental maupun social serta memperoleh perlindungan dan kesejahteraan.

Potensi dan kreativitas anak anak harus dikembangkan untuk berpartisipasi aktif dalam pengambilan keputusan atas setiap kebijakan yang berakibat dan berhubungan dengan nasib dirinya karena selama ini partisipasi anak masih belum mendapat perhatian yang memadai. Banyak fakta menunjukan bahwa masih sedikit kebijakan publik yang diambil dengan mempertimbangkan kebutuhan berdasarkan aspirasi dan suara anak. Jika hal tersebut tetap diindahkan maka anak akan hidup didalam lingkungan yang tidak ramah anak sehingga tumbuh kembangnya akan terganggu baik secara fisik maupun psikis. Jika ditinjau lebih jauh dalam arti luas maka ruang partisipasi anak dimaknai sebagai "ketersediaan ruang didalam jiwa dan hati oarng dewasa”, “ kemauan atau kesediaan” orang dewasa untuk menerima anak apa adanya, kebesaran jiwa orang dewasa untuk mendengarkan suara, pendapat, aspirasi dan keinginan serta kebutuhan anak. Sikap orang dewasa yang meremehkan terhadap pandangan anak harus dihindari karena aspirasi anak merupakan kebutuhan dasar untukmenjamin kepentingan anak tetap dapat terlindungi dari bias pandangan orang dewasa yang bisa jadi merugikan atau tidak sejalan dengan hak-hak anak. Kepentingan terbaik bagi anak merupakan suatu prinsip universal dalam partisipasi anak sehingga apapun yang dihasilkan dari proses partisipasi adalah yang menjamin kepentingan terbaik bagi anak sehingga partisipasi anak harus mempertimbangkan kepentingan usia dan kematangan anak demi menjamin kelangsungan hidup dan tumbuh kembang yang optimal (Indonesia. Kementerian Pemberdayaan Perempuan dan Perlindungan Anak, 2011b).

\section{Pemberdayaan Anak dalam Wadah Partisipasi}

Suatu tinjauan sosiologis berarti sorotan yang didasarkan pada hubungan antar manusia, hubungan antara manusia, antar kelompok serta hubungan antar manusia di kelompok, dalam proses kehidupan masyarakat, didalam proses kehidupan bermasyarakat (Soekanto, 2012, 442). Didalam proses sosialisasi terdapat berbagai pihak yang mungkin berperan yang disebut dengan lingkungan sosial. Lingkungan sosial dan latar belakang pendidikan adalah dua faktor diantara faktor- faktor lain yang mengakibatkan perbedaan pemikiran anak, sehingga anak sebagaimana orang dewasa juga mempunyai ide dan gagasan , 
ketrampilan serta kemampuan yang masing-masing anak berbeda dengan yang lain, di lingkungan anak terbentuk suatu kelompok- kelompok tertentu berdasarkan aspek diantaranya belajar, kelompok bermain, organisasi anak dan sebagainya.

Konsep partisipasi anak dapat dilihat dari 3 (tiga) sudut pandang yaitu

1. Pandangan orang dewasa

Bahwa perspektif dimana makin positif pandangan orang dewasa terhadap anak maka makin terbuka peluang bagi anak untuk berpartisipasi baik dalam proses pengambilan keputusan maupun dalam melaksanakan suatu kegiatan. Bahwa mindset seseorang dalam memandang partisipasi anak dipengaruhi oleh pendidikan, lingkungan social budaya sehingga bisa terjadi penafsiran partisipasi anak antar daerah maupun propinsi.

2. Pandangan anak

Dalam pandangannya maka dapat berarti hak yang harus dipenuhi, hak yang dijamin oleh Undang-undang sehingga posisi anak adalah sebagai penuntut kepada negara, yang dalam hal ini adalah selaku pihak yang dituntut agar hak-hak yang melekat pada diri anak dapat dipenuhi sesuai kebutuhan, minat, bakat dan kemampuan anak. Namun ia sebagai kelompok yang rentan maka anak cenderung tidak mudah dalam mendapatkan hak-haknya

3. Pandangan pemerintah

Dalam mengimplementasikan tuntutan anak, pemerintah merupakan suatu system yang dinamis yang dipengaruhi banyak factor sehingga perlu untuk dikembangkannya berbagai kebijakan untuk memastikan hak anak dapat terpenuhi sehingga dalam hal ini perlu mendorong agar anak-anak dapat menjadi warganegara yang aktif dengan cara mensosialisasikan hak partisipasi dan memfasilitasi pembentukan wadah-wadah partisipasi (Indonesia. Kementerian Pemberdayaan Perempuan dan Perlindungan Anak, 2011b).

Tanggungjawab negara sebagaimana dimuat dalam pasal 24 Undang-undang No. 35 Tahun 2014 yang menyatakan bahwa negara, pemerintah, dan pemerintah daerah menjamin anak untuk mempergunakan haknya dalam menyampaikan pendapat sesuai dengan usia dan tingkat kecerdasan anak. Kebijakan partisipasi anak adalah serangkaian aturan berupa norma, standar, prosedur dan/atau kriteria yang ditetapkan pemerintah sebagai petunjuk pelaksanaan dalam melibatkan atau mengikutsertakan seseorang yang belum berusia 18 (delapan belas) tahun dalam proses pengambilan keputusan tentang segala sesuatu yang berhubungan dengan dirinya dan dilaksanakan atas kesadaran, pemahaman serta kemauan bersama sehingga anak dapat menikmati hasil atau mendapatkan mafaat dari keputusan tersebut. Salah satu dari wadah partisipasi yang dapat dibentuk adalah Forum anak, yaitu wadah yang menampung aspirasi suara anak yang dikelola oleh anak-anak yang berusia dibawah 18 tahun yang 
bekerjasama dengan pemerintah melalui peran dengan cara memberikan masukan, pandangan dan pendapat sehubungan kebutuhan dan kepentingannya dalam proses perencanaan, pemantauan serta evaluasi kebijakanterkait program-program maupun kegiatan pembangunan daerah (Indonesia. Kementerian Pemberdayaan Perempuan dan Perlindungan Anak, 2011b).

Pertumbuhan dan perkembangan pribadi manusia selain dipengaruhi oleh faktor introvert yang dibawa sejak lahir juga dipengaruhi oleh faktor ekstrovert yang diperoleh selama menjalin interkasi dengan lingkungannya. Masa remaja merupakan periode peralihan seorang indvidu dari satu tahap ke tahap berikutnya dengan melampaui banyak perubahan baik fisik maupun psikis sehingga mereka berpotensi rentan untuk menghadapi masalah-masalah psikososial yaitu terjadinya perubahan psikis. Konflik yang dihadapi oleh remaja semakin kompleks seiring dengan perubahan pada berbagai dimensi kehidupan yang mereka alami, baik dimensi biologis, kognitif maupun moral dimana remaja mulai mampu berpikir logis serta mampu berpikir secara mandiri dan multidimensi sehingga pada periode ini mereka mulai membentuk nilai diri dan tidak lagi menerima hasil pemikiran yang kaku dan absolut dimana selama ini mereka bertahan tanpa bisa melakukan bantahan. Sikap kritis dan kemampuan dalam melihat banyaknya aspek dalam kehidupan akan mampu mereka rekonstruksi dengan pola pikir mereka yang cenderung memberontak jika ada ketidaksesuaian. Berbagai dimensi perubahan yang terjadi pada diri remaja tersebut akan menjadikan mereka bisa berhasil sebagai pribadi dengan jati diri yang positif, lebih percaya diri serta penuh dengan rasa tanggungjawab apabila peranan orangtua maupun lingkungan mereka sangat memperhatikan dan melindunginya (Prakoso, 2014, pp. 113-118).

Menghormati HAM bukan berarti memberi keistimewaan dan memanjakan manusia namun justru untuk memanusiakan manusia sebab tanpa pengakuan HAM maka nilai/martabat kemanusiaanya menjadi tidak ada. Untuk itulah manusia menjadi subyek hukum, satu posisi yang menempatkan manusia sebagai pemilik hak, kwajiban dan tanggungjawab hukum, karenanya manusia dilindungi oleh hukum (Effendi, 2012). Keberadaan Forum anak sebagai salah satu bentuk wujud wadah partisipasi bagi anak yang secara hierarki berpuncak di tingkat nasional bernama Forum Anak Nasional, berfungsi untuk menjembatani komunikasi dan interaksi antara pemerintah dengan anak-anak dalam rangka pemenuhan hak partisipasi anak sehingga diharapkan pemenuhan hak partisipai anak dapat berjalan sesuai dengan tujuannya, sebagaimana pendapat Ali (2008, p. 17) bahwa apabila interaksi sosial berjalan dengan baik maka masyarakat dapat hidup dengan tenang. Mereka dapat memperoleh hubungan baik melalui interaksi antar sesamanya baik dalam bentuk berkomunikasi melalui interaksi maupun dalam bentuk kerjasama.

Partisipasi pada dasarnya merupakan suatu bentuk keterlibatan dan keikutsertaan secara aktif, sukarela baik karena alasan dari dalam (intrinsik) maupun dari luar (ekstrinsik) 
dalam keseluruhan proses kegiatan yang bersangkutan yang mencakup: pengambilan keputusan dalam perencanaan, pelaksanaan, pengendalian serta pemanfaatan hasil-hasil kegiatan yang dicapai (Theresia, Andini, Nugraha, \& Mardikanto, 2014, p. 28). Pemberdayaan mempunyai makna dalam menyediakan sumberdaya, peluang, pengetahuan dan keahlian masyarakat untuk meningkatkan kapasitas atau kemampuannya dalam menentukan masa depannya dan berpartisipasi dalam kehidupan masyarakatnya. Menurut Adjid, keberdayaan adalah kondisi dinamik yang merefleksikan kemampuan suatu sistem sosial dalam mewujudkan tujuan atau nilai yang diidamkannya, sehingga pemberdayaan berarti sebuah usaha (program, proses) untuk mengembangkan keberdayaan guna mencapai tujuan secara mandiri (Sumaryo Gs. \& Rangga, 2015, pp. 20-29).

Sebagaimana "anak" yang dikategorikan dalam kelompok rentan maka dalam rangka untuk menghadapi tantangan dinamika perkembangan pembangunan kedepan maka anak juga harus dipersiapkan untuk memberdayakan kemampuan dirinya sehingga mereka diharapkan untuk mampu menolong dirinya sendiri karena yang paling mengetahui akan masalah, kebutuhan dan keinginan mereka adalah mereka sendiri, mampu berpartisipasi aktif dalam pengambilan keputusan khususnya tehadap setiap kebijakan yang berakibat atau berhubungan dengan kepentingan dan kebutuhan anak, mampu menegakan hak-hak asasinya atas perlindungan hukum dengan cara mengaktualisasikannya dalam aktivitas fungsi serta peran dari wadah-wadah pasrtisipasi anak yang ada, dimana mereka diharapkan dapat menjadi pelopor dan pelapor, sebagai bagian dari proses pematangan wawasan dan pengetahuan anak sebagaimana fungsi dari forum anak itu sendiri yaitu :

1. Menampung dan menyalurkan aspirasi anak

2. Mengindentifikasi kondisi sosial - budaya dan isu yang terkait dengan upaya pemenuhan hak anak di lingkungannya

3. Menyusun dan melaksanakan program kegiatan forum anak.

4. Mengkomunikasikan dan mengkoordinasikan semua kegiatan yang dilaksanakan oleh forum anak dengan pemerintah maupun masyarakat yang menjadi jejaringnya

5. Melaksanakan pembinaan dan bimbingan serta memberdayakan forum anak yang lainnya.

Dalam pandangan Unicef, agar tingkat keberdayaan suatu kelompok manusia dapat meningkatkan keberdayaannya secara optimal untuk mengubah diri dan lingkungannya, intervensi melalui konsep pemberdayaan masyarakat, dalam hal ini yaitu pada kelompok remaja adalah intervensi paling strategis. Karena remaja menempati posisi terbesar dari penduduk Indonesia sehingga kegagalan intervensi pada fase ini akan menimbulkan biaya social (social cost) yang tinggi dikemudian hari sebagai akibat dari urbanisasi, pengangguran maupun frustasi yang akan mengakibatkan adanya peningkatan kriminalitas, penggunnaan 
obat terlarang dan sebagainya (Sumaryo Gs. \& Rangga, 2015, pp. 28-29).

Partisipasi pada dasarnya merupakan suatu bentuk keterlibatan dan keikutsertaan secara aktif, sukarela baik karena alasan dari dalam (intrinsik) maupun dari luar (ekstrinsik) dalam keseluruhan proses kegiatan yang bersangkutan yang mencakup: pengambilan keputusan dalam perencanaan, pelaksanaan, pengendalian serta pemanfaatan hasil-hasil kegiatan yang dicapai (Theresia et al., 2014, p. 98). Namun tetap perlu dengan kesadaran bahwa didalam setiap hak anak, juga terdapat kewajiban-kewajiban yang harus dilakukan oleh anakanak, oleh karena itu pemenuhan hak partisipasi anak harus tetap dalam koridor memberi manfaat bagi anak-anak pada saat ini maupun pada masa yang akan dating sehingga orang dewasa yang mempertimbangkan apakah suatu kegiatan yang melibatkan anak bermanfaat atau tidak baik secara langsung maupun tidak langsung (Indonesia. Kementerian Pemberdayaan Perempuan dan Perlindungan Anak, 2011b). Oleh karena itu dalam rangka pemenuhan hak partisipasi anak maka diharapkan masyarakat dan pemerintah memberi kesempatan kepada anak untuk terlibat dan ikut serta dalam suatu aktifitas yang berhubungan dengan anak mulai dari perencanaan sampai hasilnya, maka kehadiran forum merupakan suatu peluang dan tantangan bagi anak dalam mengaktualisasikan hak partisipasinya sesuai dengan usia dan tingkat kematangan jiwanya.

\section{PENUTUP}

Pemberdayaan anak melalui wadah partisipasi anak merupakan salah satu wujud dari upaya pemajuan atas hak asasi manusia (anak), sebagai impememntasi dari pelaksanaan dan penegakan atas hak asasi manusia karena anak juga merupakan warganegara yang mempunyai hak sama pula sebagaimana warganegara yang lain dan anak adalah subyek pemilik atas hakhak dasarnya. Wujud peran serta aspirasi anak dalam pembangunan terkait kebutuhan perlindungan atas diri anak itu sendiri menggambarkan bahwa anak seharusnya tidak menjadi sekedar simbol tujuan dari setiap proses pembangunan namun anak juga bisa menjadi Pelopor bagi kemajuan penghargaan atas keperansertaanya dan partisipasinya dalam pembangunan, dalam skala penentuan kebijakan yang terbaik bagi diri dan lingkungan teman sebayanya dan anak juga bisa menjadi Pelapor atas potensi pelanggaran-pelanggaran atas hak-haknya dari lingkungan sekitarnya baik sejak dari lingkungan keluarga, sekolah, masyarakat dan lingkungan lain di sekelilingnya. Kesiapan mereka untuk menjalaninya adalah anak harus bertumbuh secara optimal secara fisik maupun psikis serta kecerdasan sosial anak dapat terasah melalui pemberdayaannya dalam wadah partisipasi seperti forum anak sebagai representasi atas hak partisipasi mereka beserta kiprah, peran dan fungsinya bagi penegakan hak asasi manusia (anak) lainnya, yang juga merupakan salah satu upaya untuk meningkatkan modal sosial agar anak sebagai pemilik hak dasarnya dan sebagai pelaku pembangunan bangsa kedepan dapat 
berkualitas.

\section{DAFTAR PUSTAKA}

Ali, Z. (2008). Sosiologi hukum. Jakarta: Sinar Grafika.

Djamal, M. (2016). Fenomena kekerasan di sekolah. Yogyakarta: Pustaka Pelajar.

Effendi, A. M. (2012). Membangun Kesadaran HAM Dalam Masyarakat Modern. In S. Arinanto \& N. Triyanti (Eds.), Memahami Hukum Dari Konstruksi Sampai Implementasi. Jakarta: Rajawali Pers.

Gultom, M. (2008). Perlindungan hukum terhadap anak dalam sistem peradilan pidana anak di Indonesia. Jakarta: Refika Aditama.

Indonesia. Kementerian Pemberdayaan Perempuan dan Perlindungan Anak. (n.d.). Sosialisasi Program Three Ends Kementrian Pemberdayaan Perempuan dan Perlindungan Anak Republik Indonesia: Mewujudkan Perempuan dan Anak Indonesia yang Berkualitas, Mandiri dan Berkepribadian.

Indonesia. Kementerian Pemberdayaan Perempuan dan Perlindungan Anak. Peraturan Menteri Negara Pemberdayaan Perempuan dan Perlindungan Anak No. 11 tahun 2011 tentang Pengembangan Kebijakan Kota Layak Anak (2011).

Indonesia. Kementerian Pemberdayaan Perempuan dan Perlindungan Anak. Peraturan Menteri Negara Pemberdayaan perempuan dan Perlindungan Anak Republik Indonesia Nomor 4 Tahun 2011 tentang Petunjuk Pelaksanaan Kebijakan Partisipasi Anak Dalam Pembangunan (2011). Indonesia. Retrieved from www.djpp.depkumham.go.id.

Indonesia. Undang-undang No. 3 Tahun 1967 tentang Pengadilan Anak (1967).

Prakoso, A. (2014). Hukum dan Psikilogi Hukum. Jakarta: LaksBang Grafika.

Prakoso, A. (2016). Hukum perlindungan anak. Yogyakarta: Laksbang Pressindo.

Rumtianing, I. (2016). Kota layak anak dalam perspektif perlindungan anak. Jurnal Ilmiah Pendidikan Pancasila Dan Kewarganegaraan, 27(1).

ttps://doi.org/10.17977/JPPKN.V27I1.5524 Savitri, N. (2008). HAM perempuan: kritik teori hukum feminis terhadap KUHP. Bandung: Refika Aditama.

Setyawan, D. (2014). IImplementasi restorasi justice dalam penanganan anak bermasalah dengan hukum. Retrieved September 8, 2017, from

http://www.kpai.go.id/artikel/implementasi-restorasi- _ justice-dalam-penanganananak-bermasalah-dengan-hukum.

Soekanto, S. (2012). Sosiologi: suatu pengantar. Jakarta: Raja Grafindo Persada.

Sumaryo Gs., K. S., \& Rangga, K. K. (2015). Pengembangan dan pemberdayaan masyarakat: konsep, teori dan aplikasinya di era otonomi daerah.

Theresia, A., Andini, K. S., Nugraha, P. G. P., \& Mardikanto, T. (2014). Pembangunan berbasis masyarakat: acuan bagi praktisi, akademisi, dan pemerhati pengembangan masyarakat (Cetakan ke). Bandung: Alfabeta. 
Wiranata, I. G. A. B. (2009). Hak Asasi (Anak) Dalam Realitas Quo Vadis? In Muladi (Ed.), Hak asasi manusia: hakekat, konsep dan implikasinya dalam perspektif hukum dan masyarakat. Bandung: Refika Aditama.

Wiyono, R. (2016). Sistem peradilan pidana anak di Indonesia (Cet. 1). Jakarta: Sinar Grafika. 